\title{
Topical Lotion Dosage Form
}

National Cancer Institute

\section{Source}

National Cancer Institute. Topical Lotion Dosage Form. NCI Thesaurus. Code C91190.

A lotion intended for administration to a body surface. 